\title{
Analisis Kesesuaian Lahan Budidaya Rumput Laut Kappaphhycus alvarezii (Doty) menggunakan Citra Satelit Di Perairan Pulau Nusa Lembongan, Bali
}

\author{
Muhammad Fatah Nashrullah ${ }^{1 *}$, A.B. Susanto ${ }^{1}$, Ibnu Pratikto', Emi Yati ${ }^{2}$ \\ ${ }^{1}$ Departemen IImu Kelautan, Fakultas Perikanan dan IImu Kelautan, Universitas Diponegoro \\ JI. Prof.H.Soedarto S.H, Tembalang,Semarang, Jawa Tengah 50275 Indonesia \\ ${ }^{2}$ Pusat Pemanfaatan Penginderaan Jauh, Lembaga Penerbangan dan Antariksa Nasional \\ Jl. Kalisari No. 8, Pekayon, Pasar Rebo, Jakarta 13710 Indonesia \\ *Corresponding author, e-mail : fatahnasrullah72@gmail.com
}

\begin{abstract}
ABSTRAK: Perairan Pulau Nusa Lembongan merupakan salah satu pulau yang berlokasi di Kab.Klungkung, Bali. Budidaya rumput laut di lokasi ini terdapat beberapa kendala dalam pengembangannya, yaitu keterbatasan pemahaman sumberdaya manusia, modal serta penentuan lokasi busisaya rumput laut. Metode penelitian yang digunakan adalam metode eksploratif dengan pendekatan analisa kuantitatif.Penelitian ini bertujuan menganalisis tingkat kesesuaian lahan budidaya dan mengetahui luasan lahan yang efektif untuk budidaya rumput laut di perairan Pulau Nusa Lembongan. Parameter yang diamati yaitu suhu, salinitas, $\mathrm{pH}$, keterlindungan, kedalaman, kecerahan, arus, substrat dasar perairan, nitrat, fosfat, oksigen terlarut (DO), klorofil-A dan muatan padatan tersuspensi (MPT). Analisis dilakukan dengan pendekatan Sistem Informasi Geografis (SIG). Hasil analisis kesesuaian lahan untuk pengembangan budidaya rumput laut di perairan Pulau Nusa Lembongan yang sangat sesuai sebesar 3.375,65 Ha. Sedangkan luas lahan yang efektif sebesar 2.025,39 Ha yaitu 60\% dari luas sangat sesuai dengan jumlah rakit yang dioperasikan sebesar 810.156 unit dan ukuran rakit 1 x25 m serta total produksi pada satu musim panen sebesar $89.117,16$ ton/siklus panen.
\end{abstract}

Kata kunci: Kesesuaian Lahan; Budidaya; Rumput Laut; Nusa Lembongan

\section{Land Suitability Assesment of Kappaphhycus alvarezii (Doty) Seaweed Cultivation Using Satellite Images In Nusa Lembongan, Bali}

\begin{abstract}
The waters of Nusa Lembongan Island are one of the islands located in Klungkung Regency, Bali. Seaweed cultivation in this location has several features in its development, namely limited understanding of human resources, capital and determining the location of seaweed busses. The research method used is an exploratory method with a quantitative analysis approach.This study aims to analyze the suitability level of cultivated land and determine the effective land area for seaweed cultivation in Nusa Lembongan Island. The parameters temperature, salinity, $\mathrm{pH}$, water protection, depth, brightness, current, bottom water substrate, nitrate, phosphate, dissolved oxygen (DO), chlorophyll-A, and suspended solids charge (MPT). The analysis was carried out with a Geographical Information System (GIS) approach. The results of the land suitability analysis for the development of seaweed cultivation in Nusa Lembongan which are very suitable are 3,375.65 hectares. While the effective land area is 2,025.39 ha, which is $60 \%$ of the area, which corresponds to the number of rafts that are operated at 810,156 units, and the size of the raft is $1 \times 25 \mathrm{~m}$ and the total production in one harvest season is 89,117.16 tons/harvest cycle.
\end{abstract}

Keywords: Land Suitability; Cultivation; Seaweed; Nusa Lembongan

\section{PENDAHULUAN}

Rumput laut merupakan salah satu komoditas perikanan potensial di Indonesia yang memiliki nilai ekonomis tinggi (Priono, 2016). Berdasarkan data hasil produksi rumput laut, Indonesia mampu memproduksi sebesar 1,14 ton/ $\mathrm{km}$, dimana angka ini merupakan angka terendah dari negara lain yaitu mencapai 4,55 ton $/ \mathrm{km}$ (Valderrama et al., 2013). Rendahnya produktifitas 
rumput laut ini dikarenakan kurangnya infrastruktur, teknologi serta kebijakan yang diterapkan. Keberhasilan budidaya dipengaruhi faktor fisika, kimia dan biologi, serta pemilihan metode atau teknik budidaya yang digunakan (Susanto, 2005). Menurut Maryunus et al. (2019), terdapat beberapa faktor yang perlu diperhatikan dalam produksi budidaya rumput laut, salah satu faktor terpentingnya yaitu pemilihan lokasi atau lahan yang akan digunakan dalam budidaya rumput laut. Pemilihan lokasi yang tepat dapat menentukan tingkat keberhasilan dari budidaya rumput laut tersebut (Anggadiredja et al., 2006). Penentuan lokasi ini juga mempertimbangkan faktor faktor yang dapat mempengaruhi pertumbuhan dan penyebaran rumput laut seperti faktor oseanografi meliputi faktor fisik, kimia dan pergerakan atau dinamika air laut serta substrat perairan (Ain et al., 2014).

Nusa Lembongan adalah salah satu pulau di Indonesia yang memiliki potensi ekonomi dibidang rumput laut yang cukup tinggi. Budidaya rumput laut di Pulau Nusa Lembongan termasuk sebagai komoditi terbesar dan penghasil rumput laut terbaik di Pulau Bali dalam pengembangan sektor perikanan Kabupaten Klungkung (Muharara dan Arif, 2018). Untuk mendukung kegiatan tersebut perlu dilakukan analisis kesesuaian lahan dimana dalam menentukan lokasi budidaya rumput laut perlu diperhatikan beberapa persyaratan sebagai indikator yang mendukung kegiatan tersebut.

Saat ini, penginderaan jauh dan sistem informasi geografis (SIG) adalah salah satu teknologi yang dapat digunakan untuk mendapatkan informasi potensi kesesuaian lahan untuk budidaya rumput laut. Teknologi ini dapat membantu dalam mengintegrasikan data lapangan, analisis spasial dan mengevaluasi status kesesuaian lokasi. Penelitian ini bertujuan untuk menganalisa parameter kesesuaian lahan dan mengetahui luasan lahan yang efektif untuk pengembangan budidaya rumput laut di perairan Pulau Nusa Lembongan

\section{MATERI DAN METODE}

Penelitian ini dilakukan pada bulan Oktober 2020 di perairan Pulau Nusa Lembongan, Bali. Materi yang digunakan dalam penelitian ini adalah berupa data parameter hidro-oseanografi dengan menggunakan data primer dan sekunder de perairan Pulau Nusa Lembongan. Pengambilan data dilakukan pada 10 titik stasiun pengamatan (Gambar 1). Data primer yang digunakan adalah data parameter fisika oseanografi (suhu, salinitas, $\mathrm{pH}$, keterlindungan, kecerahan perairan dan substrat dasar perairan), data parameter kimia oseanografi (nitrat, fosfat, oksigen terlarut (DO)) dan data parameter biologi oseanorafi (klorofil-A). Sedangkan data sekunder yang digunakan sebagai data pendukung adalah data batimetri yang didapatkan dari Pusat Pemanfaatan Penginderaan Jauh (PUSFATJA LAPAN), citra satelit digital globe yang digunakan sebagai acuan dalam pembuatan peta lokasi survei penelitian, citra Landsat 8 untuk mengetahui konsentrasi material padatan tersuspensi (MPT) dan karakteristik perairan dangkal di lokasi penelitian, data arus dan angin tahunan dari Marine Copernicus tahun 2020 dan Peta RBI dari Badan Informasi Geospasial (BIG).

Metode yang digunakan dalam penelitian ini adalah metode eksploratif. Metode ini bertujuan untuk mengetahui tingkat kesesuaian lahan budidaya rumput laut di perairan Pulau Nusa Lembongan. Analisis penelitian yang digunakan adalah metode kuantitatif. Hasil yang didapatkan dari penelitian ini berupa luasan kesesuaian lahan untuk budidaya rumput laut.

Pengolahan citra Landsat 8 dilakukan pada Google Earth Engine. Pengolahan tersebut dilakukan untuk mengetahui substrat pada karakteristik perairan dangkal. Tahapan pengolahan yang dilakukan diantaranya penajaman citra dengan metode Lyzenga pendekatan Depth Invariant Index untuk mendapatkan nilai koefisien atenuasi perairan (ki/kj). Depth Invariant Index digunakan untuk mengoreksi citra kolom air dengan nilai digital berupa indeks objek habitat dasar perairan dangkal. Berikut persamaan rumus algoritma Lyzenga (Lyzenga,1981). Dasar asumsi untuk koreksi kolom air tersebut adalah sinar yang masuk ke dalam kolom air berkurang secara eksponensial dengan semakin bertambahnya kedalaman air (atenuasi). Pada sinar tampak, sinar merah teratenuasi lebih cepat daripada sinar biru dan hijau. Berikut merupakan algoritma yang digunakan. 


$$
\begin{aligned}
& \text { If } \mathrm{i} 1 / \mathrm{i} 2<1 \text { then }\left(\log (\mathrm{I} 3)+\left(\mathrm{ki} / \mathrm{kj}^{*} \log (\mathrm{I} 2)\right)\right) \text { else null } \\
& \text { Keterangan : } \mathrm{i} 1 \text { = band } 5 ; \mathrm{i} 2=\text { band } 3 ; \mathrm{i} 3=\text { band } 2
\end{aligned}
$$

Tahapan selanjutnya adalah analisa material padatan tersuspensi (MPT). Pengolahan data MPT ini dilakukan dengan penggabungan citra, cropping citra, koreksi atmosferi dan land masking. Algoritma yang digunakan adalah sebagai berikut:

$$
\operatorname{MPT}(\mathrm{mg} / \mathrm{l})=3,323 \times \exp (34,099 \times \operatorname{Rrs}(\lambda 4))
$$

Keterangan : MPT = material padatan tersuspensi; $\operatorname{Rrs}(\lambda 4)=$ nilai reflektan kanal merah

Data - data yang sudah didapatkan kemudian akan diinterpolasi untuk memprediksi nilai grid yang tidak terwakili oleh titik sampel. Metode interpolasi yang digunakan yaitu Inverse Distance Weighting (IDW). Proses selanjutnya yaitu pembobotan (weighting) dengan metode skoring. Setiap parameter memiliki skor dan bobot yang berbeda - beda sesuai dengan tingkat pengaruh dari masing - masing parameter terhadap hasil kesesuaian lahan rumput laut. Setiap parameter dibagi dalam beberapa kelas. Setiap kelas akan memperoleh nilai akhir yang merupakan hasil dari penjumlahan skor dari semua parameter. Skor yang diberikan pada setiap parameter kesesuaian budidaya rumput laut dapat dilihat pada Tabel 1.

Menurut Jailani et al. (2015), setiap daerah akan memiliki nilai kesesuaian dari setiap parameter yang dianggap paling penting dalam proses penentuan kesesuaian lahan. Rumus yang digunakan untuk menentukan total bobot nilai menurut Jailani et al. (2015).
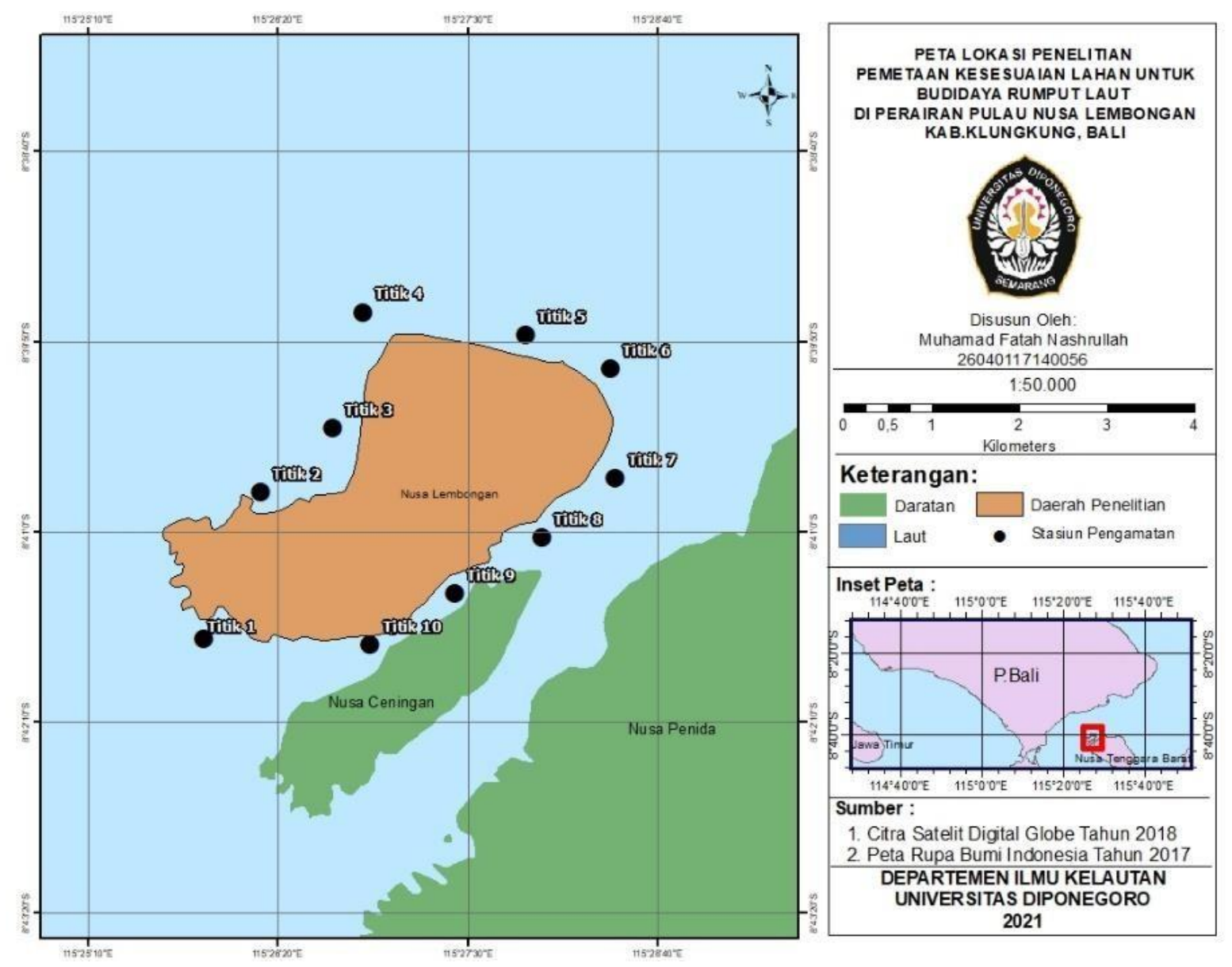

Gambar 1. Peta Lokasi Penelitian 
Tabel 1. Skor Kesesuaian Lahan BudidayaRumput Laut

\begin{tabular}{|c|c|c|c|c|}
\hline \multirow{2}{*}{ Parameter } & \multirow{2}{*}{ Kisaran } & \multicolumn{2}{|c|}{ Angka } & \multirow{2}{*}{ Skor (AxB) } \\
\hline & & Penilaian $(A)$ & Bobot (B) & \\
\hline \multirow[t]{3}{*}{ Keterlindungan } & Terbuka & 1 & 3 & 3 \\
\hline & Terlindung & 3 & & 9 \\
\hline & Sangat Terlindung & 5 & & 15 \\
\hline \multirow[t]{3}{*}{ Arus (cm/dt) } & $<10 \&>40$ & 1 & 3 & 3 \\
\hline & $>10-<25 \&>40-60$ & 3 & & 9 \\
\hline & $25-40$ & 5 & & 15 \\
\hline \multirow[t]{3}{*}{ Kedalaman (m) } & $<2 \&>10$ & 1 & 3 & 3 \\
\hline & $2-<3$ atau $>5-<10$ & 3 & & 9 \\
\hline & $3-5$ & 5 & & 15 \\
\hline \multirow{4}{*}{$\begin{array}{l}\text { Dasar perairan } \\
\text { (Substrat) }\end{array}$} & Lumpur \& Karang & 1 & 3 & 3 \\
\hline & Pasir Berlumpur Sedang & 3 & & 9 \\
\hline & Pasir Halus, Pecahan & 5 & & \\
\hline & karang \& Makro Alga & & & 15 \\
\hline \multirow[t]{3}{*}{ Salinitas (ppt) } & $<25 \&>37$ & 1 & 3 & 3 \\
\hline & $>25-<28$ atau $>34-<37$ & 3 & & 9 \\
\hline & $28-34$ & 5 & & 15 \\
\hline \multirow[t]{3}{*}{ Suhu $\left({ }^{\circ} \mathrm{C}\right)$} & $<20 \&>30$ & 1 & 3 & 3 \\
\hline & $20-24$ & 3 & & 9 \\
\hline & $24-30$ & 5 & & 15 \\
\hline \multirow[t]{3}{*}{ MPT (mg/l) } & $>80$ & 1 & 2 & 2 \\
\hline & $>25->80$ & 3 & & 6 \\
\hline & $<25$ & 5 & & 10 \\
\hline \multirow[t]{3}{*}{$\mathrm{pH}$} & $<4$ atau $>9,5$ & 1 & 2 & 2 \\
\hline & $4-6,4$ atau $8,5-9$ & 3 & & 6 \\
\hline & $6,5-8,5$ & 5 & & 10 \\
\hline \multirow[t]{3}{*}{$\mathrm{DO}(\mathrm{mg} / \mathrm{l})$} & $<3$ & 1 & 3 & 3 \\
\hline & $3-7$ & 3 & & 9 \\
\hline & $>7$ & 5 & & 15 \\
\hline \multirow[t]{3}{*}{ Nitrat (mg/l) } & $<0,01$ atau $>0,5$ & 1 & 2 & 2 \\
\hline & $>0,01-<0,04$ atau $>0,1-<0,5$ & 3 & & 6 \\
\hline & $0,04-0,1$ & 5 & & 10 \\
\hline \multirow[t]{3}{*}{ Fosfat $(\mathrm{mg} / \mathrm{l})$} & $<0,01$ atau $>1$ & 1 & 2 & 2 \\
\hline & $>0,01-<0,1$ atau $>0,2-<1$ & 3 & & 6 \\
\hline & $0,1-0,2$ & 5 & & 10 \\
\hline \multirow[t]{3}{*}{ Klorofil A (mg/l) } & $<1$ & 1 & 2 & 2 \\
\hline & $1,1>2$ & 3 & & 6 \\
\hline & $>2,1$ & 5 & & 10 \\
\hline Kecerahan & $<2,9$ & 1 & 2 & 2 \\
\hline \multirow[t]{3}{*}{ Perairan (Meter) } & & 3 & & 6 \\
\hline & $>3-4,9$ & 5 & & 10 \\
\hline & $>5$ & & & \\
\hline \multicolumn{5}{|c|}{$\begin{array}{l}\text { Sumber: Modifikasi SNI } 7673.2 \text { (2011), Agustina (2017), Gazali et al. (2013), Nirmala et al. (2014), } \\
\text { Akib et al. (2015) dan Valentino et al. (2018). }\end{array}$} \\
\hline
\end{tabular}


Journal of Marine Research Vol 10, No.3 Agustus 2021, pp. 345-354

Tabel 2. Kelas Kesesuaian Lahan

\begin{tabular}{ll}
\hline \multicolumn{1}{c}{ Nilai (skor) } & \multicolumn{1}{c}{ Kelas } \\
\hline $33-44$ & Tidak Sesuai (S3) \\
$44,1-88$ & Sesuai (S2) \\
$88,1-132$ & Sangat Sesuai (S1) \\
\hline
\end{tabular}

\section{HASIL DAN PEMBAHASAN}

Hasil dari pengamatan yang telah dilakukan menunjukkan bahwa Nusa Lembongan adalah pulau yang memiliki potensi ekonomi di bidang rumput yang cukup tinggi. Budidaya rumput laut di Pulau ini termasuk sebagai komoditi terbesar dan penghasil rumput laut terbaik di Bali dalam pengembangan sektor perikanan Kabupaten Klungkung (Muharara dan Arif, 2018). Produksi rumput laut yang terjadi di pulau ini mencapai 100.000/ton pada tahun 2016 (Armiyanti, 2015). Kondisi pesisir di Pulau Nusa Lembongan ini di dominasi oleh substrat pasir, terumbu karang dan lumpur (Gambar 2). Menurut Burdames dan Ngangi (2014) kondisi pesisir dengan substrat pasir dan pecahan karang dipandang baik untuk dilakukanya budidaya rumput laut.

Perairan Nusa Lembongan juga memiliki keterlindungan lokasi yang baik. Berdasarkan hasil pengolahan yang disajikan pada Gambar 3, diketahui bahwa bagian timur dan selatan pulau memiliki daerah yang sangat terlindung. Dikatakan sangat terlindung karena perairan tersebut dikelilingi oleh pulau - pulau kecil dan tutupan karang panjang yang mampu meredam gelombang. Kondisi ini memberikan keuntungan kepada pembudidaya karena akan memberikan pertumbuhan yang paling baik. Sedangkan bagian barat pulau memiliki daerah yang tidak terlindung. Dikatakan tidak terlindung dikarenakan perairan tersebut terbuka ke laut lepas dan tidak terdapat karang penghalang yang bisa memberikan wilayah tersebut akan terlindung oleh adanya arus dan gelombang yang besar. Arus dan gelombang besar ini akan menyebabkan kerusakan pada konstruksi budidaya rumput laut.

Selain terlindungi dan kondisi substrat, kesuburan suatu lokasi budidaya ditentukan oleh adanya arus (Kotiya et al., 2011). Kecepatan arus merupakan faktor ekologi yang penting dalam budidaya rumput laut dimana melalui pergerakan air ini dapat menyuplai nutrient, melarutkan oksigen, menyebarkan plankton dan menghilangkan lumpur yang sangat dibutuhkan tersuplai dan terdistribusi untuk pertumbuhan rumput laut. Berdasarkan hasil pengolahan data arus permukaan, menunjukkan hasil yang cukup baik untuk dilakukan budidaya rumput laut (Gambar 4). Kecepatan arus permukaan laut perairan pulau Nusa Lembongan tahun 2020 berkisar antara $10-64,9 \mathrm{~cm} / \mathrm{dt}$ dan rata - rata memiliki kecepatan sebesar $33,5 \mathrm{~cm} / \mathrm{dt}$. Kecepatan tersebut sesuai dengan kisaran besaran kecepatan arus yang baik untuk budidaya. Hal ini sesuai dengan pernyataan Parenrengi et al. (2012) dimana kecepatan arus yang dianggap baik untuk budidaya rumput laut adalah antara $20-40 \mathrm{~cm} / \mathrm{dt}$.

Kedalaman merupakan salah satu faktor penentu pada proses budidaya rumput laut. kedalaman lokasi budidaya ini akan berpengaruh pada produktivitas perairan, suhu, penetrasi cahaya serta unsur hara untuk pertumbuhan rumput laut. Kedalaman juga berperan dalam menentukan metode budidaya rumput laut. Berdasarkan hasil pengamatan, kedalaman perairan lokasi ini berkisar 1-10 meter. Metode budidaya yang umum digunakan di Pulau Nusa Lembongan yaitu sistem tanam dasar dan petakan.

Kecerahan merupakan parameter yang berhubungan erat dengan besarnya penetrasi cahaya ke dalam perairan. Pertumbuhan rumput laut sangat bergantung dari kecerahan suatu perairan. Semakin cerah perairan tersebut akan semakin dalam cahaya matahari yang dapat menembus ke dalam perairan. Rumput laut membutuhkan cahaya matahari dalam mekanisme fotosintesis. Berdasarkan hasil pengamatan, perairan ini memiliki perairan yang cerah dimana kondisi ini sangat baik untuk budidaya rumput laut.

Hasil pengamatan menunjukkan nilai salinitas di perairan pulau Nusa Lembongan berkisar antara 30-35 ppt. Kisaran tersebut masih berada pada kisaran yang sangat sesuai untuk pertumbuhan rumput laut. Menurut Yuliyana et al. (2015), Salinitas perairan pada lokasi budidaya 
yang baik yaitu berkisar antara 28-35 ppt. Kisaran tersebut dapat meningkatkan klorofil sampel ganggang sehingga membuat rumput laut tumbuh optimal.

Suhu berperan penting dalam proses fotosintesis dimana semakin tinggi intensitas matahari dan semakin optimum kondisi suhu, maka akan semakin tinggi pula hasil fotosintesis yang dihasilkan. Berdasarkan hasil pengamatan, diperoleh nilai suhu perairan pulau Nusa Lembongan yaitu memiliki kisaran antara $22,6-28,5^{\circ} \mathrm{C}$. Rumput laut dapat tumbuh dengan baik pada kisaran suhu $26-32{ }^{\circ} \mathrm{C}$ (DKP, 2006).

\section{Kondisi Kualitas Perairan}

Analisis kesesuaian lokasi budidaya rumput laut pada penelitian ini juga didasarkan pada beberapa parameter yang disesuaikan dengan kondisi perairan yaitu, kedalaman, kecerahan, salinitas, suhu, sebaran MPT, $\mathrm{pH}$, oksigen terlarut (DO), nitrat, fosfat dan klorofil-a. Hasil pengamatan parameter pada 10 titik sampling dapat dilihat pada Tabel 1.
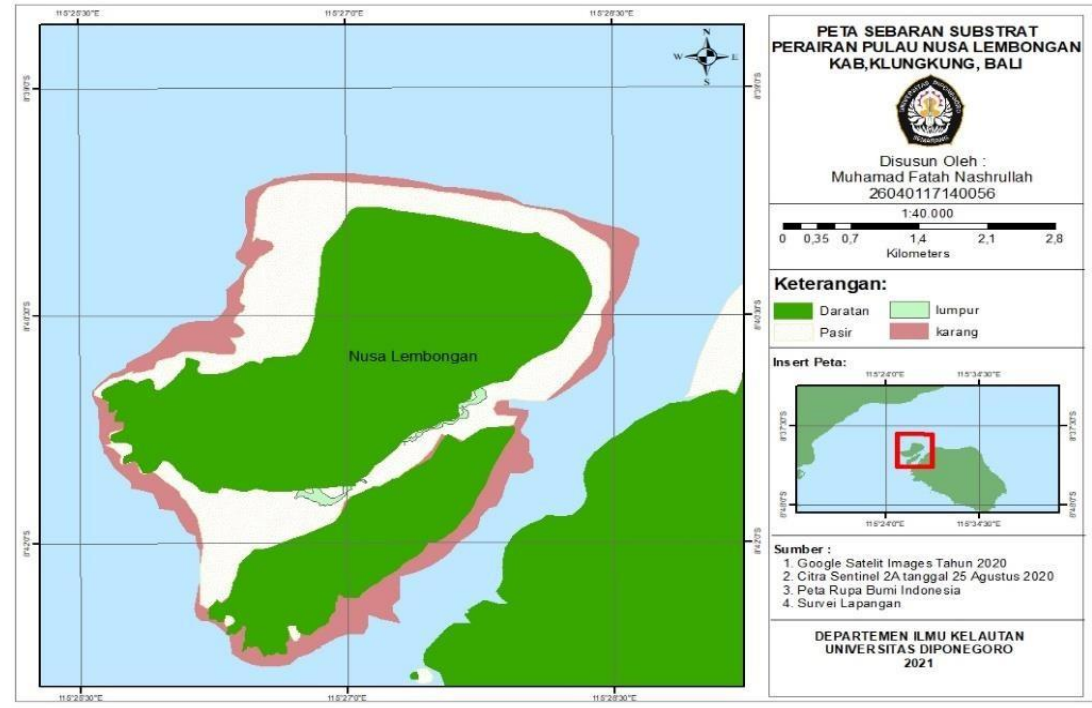

Gambar 2. Peta Sebaran Substrat di Perairan Pulau Nusa Lembongan
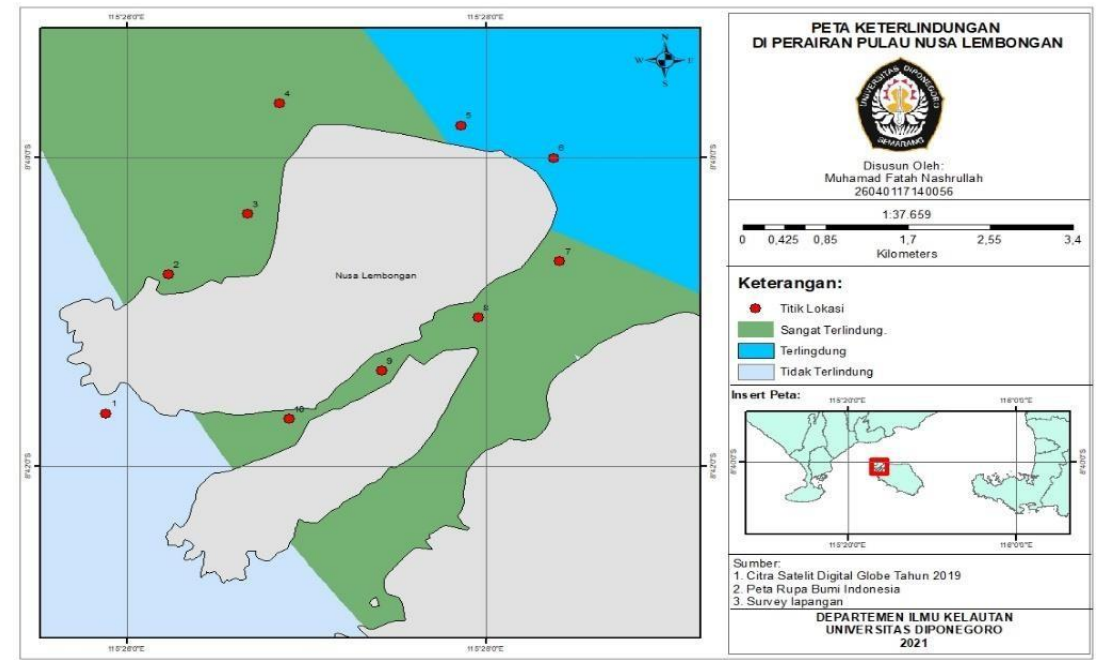

Gambar 3. Peta Keterlindungan Perairan Pulau Nusa Lembongan 


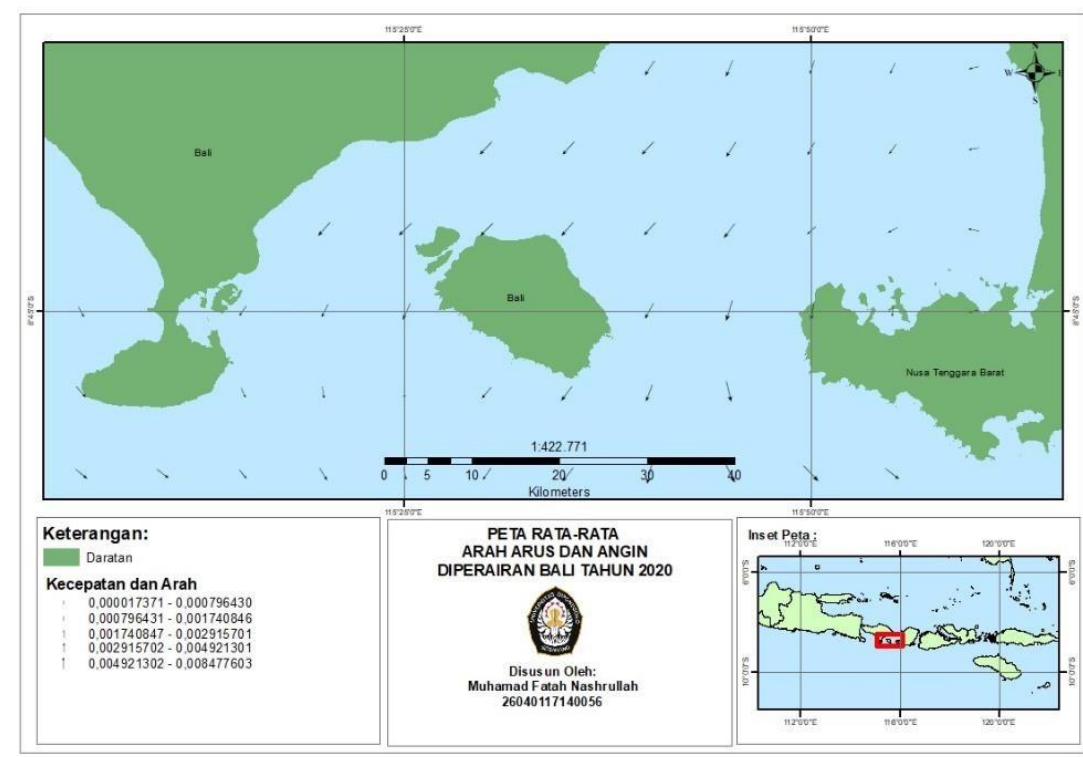

Gambar 4. Rata-rata arus perairan bali Tahun 2020

Konsentrasi MPT di perairan pulau Nusa Lembongan memiliki kisaran $16-107 \mathrm{mg} / \mathrm{l}$. Perbedaan nilai pada setiap titik pengambilan sampel disebabkan oleh komposisi material dasar perairan serta pergerakan massa air terhadap substrat. Nilai MPT yang tinggi akan menghambat penetrasi cahaya ke dalam air dan mengakibatkan terganggunya proses fotosintesis yang dilakukan oleh rumput laut. Nilai derajat keasamaan hasil pengamatan menunjukkan bahwa perairan pulau Nusa Lembongan masih berada dalam kisaran yang sangat sesuai untuk budidaya rumput laut. Berdasarkan hasil pengamatan, diketahui nilai $\mathrm{pH}$ berkisar antara 7,45 -8,07. Untuk pertumbuhan optimal, rumput laut membutuhkan $\mathrm{pH}$ 7,0 - 9,0 dengan kisaran sangat sesuai 7,58,5 (Bakosurtanal, 2005).

Hasil pengukuran secara in situ terhadap oksigen terlarut di perairan Nusa Lembongan memiliki kisaran nilai 2,69 - 5,68 mg/l dengan nilai rata - rata untuk sepuluh titik sampling yaitu $3,92 \mathrm{mg} / \mathrm{l}$. Perbedaan nilai kandungan oksigen terlarut dikarenakan adanya pergerakan dan percampuran massa air. DO dalam perairan dapat menjadi faktor pembatas untuk pertumbuhan rumput laut, dikarenakan DO diperlukan untuk proses respirasi. Berdasarkan hasil pengukuran, diketahui bahwa dari sepuluh titik sampling terdapat satu titik yang dikategorikan tidak sesuai yaitu titik dua. Konsentrasi DO untuk menunjang budidaya rumput laut adalah $3-8$ $\mathrm{mg} / \mathrm{l}$ (Ditjenkanbud, 2008).

Secara umum di perairan, nitrat dan fosfat merupakan nutrien terpenting yang dapat menentukan pertumbuhan rumput laut. Pertumbuhan dapat tercapai dengan baik apabila rumput laut tercukupi akan nitrat dan fosfat, karena nitrat dan fosfat berperan dalam pengaturan metabolism dan reproduksi. Dari hasil pengukuran, diketahui kandungan nitrat berkisar antara 0,21-1,15 mg/l. Nilai tersebut cukup tinggi, ini mengindikasikan bahwa perairan pulau Nusa Lembongan kurang subur. Kesuburan perairan untuk budidaya rumput laut yang optimal berada pada kisaran 0,04-0,1 mg/l (Nugroho, 2014). Jika kandungan nitrat terlalu tinggi maka akan berdampak pada pertumbuhan rumput laut karena dapat mendatangkan alga sebagai competitor dalam mendapatkan nutrisi. Perbedaan kandungan nitrat disebabkan oleh letak suatu perairan tersebut. Perairan yang dekat dengan pemukiman penduduk akan cenderung memiliki kandungan nitrat yang tinggi, dikarenakan adanya aktivitas pemukiman di dekat perairan yang menyebabkan pembusukan sampah - sampah organik. Hasil pengukuran fosfat pada setiap titik sampling memiliki nilai bervariasi dengan kisaran nilai 0,03-1,02 mg/l. Perbedaan tersebut disebabkan oleh lokasi dan waktu pengukuran. Sedangkan kandungan fosfat diduga disebabkan oleh adanya bahan organik berupa limbah domestik dari pulau - pulau yang berada di dekat Nusa Lembongan yaitu Nusa Ceningan, Nusa Penida dan Pulau Bali yang dimana pulau tersebut merupakan pulau 
yang padat pemukiman. Hasil pengukuran rata - rata pada tahun 2020 terhadap klorofil-a pada setiap titik sampling bervariasi dengan kisaran 0,031-0,87 $\mathrm{mg} / \mathrm{l}$. Nilai klorofil-a yang baik menunjukkan bahwa di perairan tersebut memiliki tingkat kecerahan, $\mathrm{pH}$, nitrat dan fosfat yang sangat baik.

\section{Kesesuaian Lahan Budidaya Rumput Laut}

Berdasarkan hasil analisis spasial berupa overlay variabel interpolasi serta pembobotan (weighting) diperoleh kelas kesesuaian lahan untuk budidaya rumput laut di perairan pulau Nusa Lembongan (Gambar 5). Hasil yang didapat adalah luasan wilayah yang tidak sesuai (S3) sebesar 723,35 ha, sesuai (S2) sebesar 723,35 ha dan sangat sesuai (S1) sebesar 3.375,65 ha. Dari hasil tersebut dapat diketahui pula metode budidaya yang berpeluang besar dikembangkan di perairan pulau Nusa Lembongan yaitu metode sistem tanam dasar. Metode ini akan sesuai dengan topografi pantai yang landai dengan dasar perairan berupa pasir serta karang. Pada tahun $2013-$ 2017, petani rumput laut di Nusa Lembongan mengalami kegagalan panen. Salah satu penyebab kegagalan tersebut dikarenakan oleh hama ikan dan kondisi iklim yang tidak stabil yang menimbulkan berbagai penyakit bagi rumput laut (Pradnyana et al., 2019). Untuk mengurangi masalah tersebut, metode penggunaan jaring kantong dapat digunakan. Menurut Susanto (2005), metode ini dapat mengurangi kemungkinan kerontokan thallus karena adanya ombak sehingga rumput laut tidak akan jatuh ke dasar laut atau terbawa arus, Kemudian akan terhindar dari predator-predator yang akan mengganggu pertumbuhan rumput laut.

Penentuan kesesuaian lahan budidaya rumput laut juga perlu memperhatikan daya dukung lingkungan. Daya dukung ini menjadi konsep penting untuk manajemen berbasis ekosistem yang membantu menentukan batas atas produksi budidaya, batas ekologis dan penerimaan sosial (Radiarta et al, 2018). Pendugaan daya dukung lingkungan perairan pulau Nusa Lembongan untuk pengembangan budidaya rumput laut dilakukan dengan tiga pendekatan yaitu luas area budidaya, jumlah petakan tanam dasar dan total produksi rumput laut. Berdasarkan analisis spasial, didapatkan hasil luas efektif lahan perairan untuk digunakan dalam kegiatan budidaya sebesar 2.025,39 ha. Metode sistem tanam dasar yang digunakan mengacu pada WWF (2014) yaitu menggunakan jarak 15-25 meter sejajar arah arus dan lebar 1 meter $\left(25 \mathrm{~m}^{2}\right.$ atau 0,0025 ha) dengan jumlah rakit sebanyak 810.156 unit. Berdasarkan perhitungan yang telah dilakukan didapatkan pula hasil produksi bersih rumput laut di perairan pulau Nusa Lembongan sebesar 110 $\mathrm{kg}$, sehingga dapat diketahui total produksi pada satu musim panen sebesar $89.117,16$ ton/siklus panen.

Tabel 1. Hasil Nilai Rata-Rata Pengamatan Parameter Kualitas Air

\begin{tabular}{ccccccccccc}
\hline \multirow{2}{*}{ Kualitas Air } & \multicolumn{10}{c}{ Titik Sampling } \\
\cline { 2 - 11 } & 1 & 2 & 3 & 4 & 5 & 6 & 7 & 8 & 9 & 10 \\
\hline Kedalaman (m) & 10 & 1 & 1 & 3 & 6 & 8 & 10 & 1 & 1 & 1 \\
Kecerahan (m) & 10 & 1 & 1 & 3 & 6 & 8 & 10 & 1 & 1 & 1 \\
Salinitas (ppt) & 33 & 31 & 34 & 30 & 35 & 33 & 33 & 33 & 30 & 33 \\
Suhu $\left({ }^{\circ} \mathrm{C}\right)$ & 28,5 & 25,2 & 26,4 & 22,6 & 27 & 27,7 & 26,7 & 27,4 & 23,2 & 23,2 \\
MPT (mg/l) & 57 & 107 & 19 & 17 & 32 & 16 & 24 & 94 & 83 & 88 \\
pH & 8,01 & 7,8 & 7,5 & 7,8 & 8,07 & 7,78 & 7,75 & 7,45 & 7,85 & 7,82 \\
DO $(\mathrm{mg} / \mathrm{l})$ & 3,65 & 2,69 & 4,02 & 4,07 & 3,38 & 4,2 & 4,43 & 5,68 & 3,38 & 3,69 \\
Nitrat $(\mathrm{mg} / \mathrm{l})$ & 1,15 & 0,86 & 0,24 & 0,43 & 0,41 & 0,21 & 0,35 & 0,39 & 0,34 & 0,25 \\
Fosfat $(\mathrm{mg} / \mathrm{l})$ & 1,02 & 0,153 & 0,032 & 0,072 & 0,098 & 0,03 & 0,17 & 0,18 & 0,16 & 0,11 \\
Klorofil-A & 0,04 & 0,031 & 0,062 & 0,87 & 0,52 & 0,13 & 0,047 & 0,035 & 0,034 & 0,064 \\
\hline
\end{tabular}




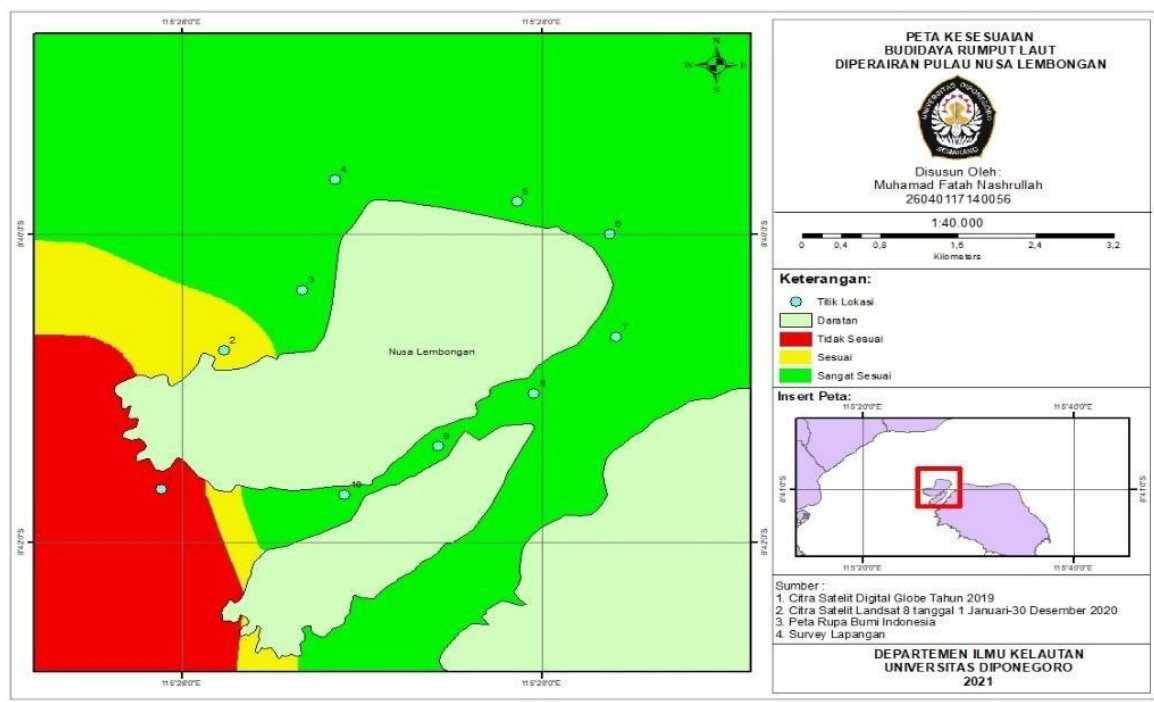

Gambar 5. Peta Kesesuaian Lahan Budidaya Rumput Laut

\section{KESIMPULAN}

Hasil analisis kesesuaian lahan untuk pengembangan budidaya rumput laut di Pulau Nusa Lembongan, Bali yang sangat sesuai sebesar 3.375,65 Ha. Sedangkan luas lahan yang efektif untuk pengembangan budidaya rumput laut sebesar 2.025,39 Ha yaitu 60\% dari luas sangat sesuai dengan jumlah rakit yang dioperasikan sebesar 810.156 unit serta ukuran rakit 1 x25 m dan total produksi pada satu musim panen sebesar $89.117,16$ ton/siklus panen.

\section{DAFTAR PUSTAKA}

[BAKOSURTANAL] Badan Koordinasi Survei dan Pemetaan Nasional, 2005, Prosedur dan Spesifikasi Teknis Analisis Kesesuaian Budidaya Rumput Laut, Pusat Survei Sumberdaya Alam Laut, Badan Koordinasi Survei dan Pemetaan Nasional, Cibinong Bogor, $36 \mathrm{hlm}$

[Ditjenkanbud] Direktorat Jendral Perikanan Budidaya, 2008, Petunjuk Teknis Budidaya Rumput Laut, Direktorat Jendral Perikanan Budidaya, Departemen Kelautan dan Perikanan, Jakarta, $41 \mathrm{hlm}$.

[DKP] Departemen Kelautan dan Perikanan. 2006. Petunjuk Teknis Budidaya Rumput Laut Eucheuma spp, Jakarta.

[SNI] Standar Nasional Indonesia, 2011, Produksi Bibit Rumput Laut Kotoni (Eucheuma cottonii) Bagian 2: Metode longline, Badan Standarisasi Nasional, Jakarta.

Agustina, N.A., Prasita, V.D., \& Wijaya, N.I, 2017. Kriteria Lahan Untuk Budidaya Rumput Laut (Eucheuma cottonii) Di Pulau Gili Genting, Madura, Seminar Nasional Kelautan XII. p.B109B116

Ain, N., \& Widyorini, N, 2014, Hubungan Kerapatan Rumput Laut Dengan Substrat Dasar Berbeda Di Perairan Pantai Bandengan, Jepara. Management of Aquatic Resources Journal, 3(1):99-107. DOI: $10.14710 /$ marj.v3i1.4426

Akib, A., Litaay, M., Ambeng, A., \& Asnady, M., 2015, Kelayakan Kualitas Air Untuk Kawasan Budidaya Eucheuma Cottoni Berdasarkan Aspek Fisika, Kimia Dan Biologi Di Kabupaten Kepulauan Selayar, Jurnal Pesisir dan Laut Tropis, 3(1):25-36. DOI: 10.35800/ jplt.3.1.2015.9203

Anggadiredja, J.A., Zatnika, H., Purwoto \& Istini, S. 2006, Rumput Laut, Pembudidayaan, Pengolahan dan Pemasaran Komoditas Perikanan Potensial, Penebar Swadaya, Jakarta. 
Armiyanti, N.P.N.N., 2015. Tingkat Produktivitas Budidaya Rumput Laut Pada Perairan Pantai Di Kecamatan Nusa Penida Kabupaten Klungkung. Jurnal Pendidikan Geografi Undiksha, 3(1):112 DOI: $10.23887 /$ jjpg.v3i1.20452

Burdames, Y. \& E.L.A. Ngangi. 2014. Kondisi Lingkungan Perairan Budidaya Rumput Laut di Desa Arakan, Kabupaten Minahasa Selatan. Jurnal Budidaya Perairan 2(3):69-75. DOI: 10.35800/ bdp.2.3.2014.5706

Gazali. I., Widiatmono, B.R., \& Wirosoedarmo, R., 2013. Evaluasi Dampak Pembuangan Limbah Cair Pabrik Kertas Terhadap Kualitas Air Sungai Klinter Kabupaten Nganjuk, Jurnal Keteknikan Pertanian Tropis dan Biosistem, 1(2):1-8.

Jailani, A.Q., Herawati, E.Y. \& Semedi, B, 2015. Studi Kelayakan Lahan Budidaya Rumput Laut Eucheuma cottonii di Kecamatan Bluto Sumenep Madura Jawa Timur. Jurnal Manusia dan Lingkungan, 22(2):211-216. DOI: 10.22146/jml.18744

Kotiya, A.S., Gunalan, B., Parmar, H.V., Jaikumar, M., Dave, T., Solanki, J.B., \& Nayan, P.M., 2011, Growth Comparison Of The Seaweed Kappaphycus alvarezii In Nine Different Coastal Areas of Gujarat Coast, India, Advances in Applied Science Research, 2(3): 99-106.

Maryunus, R.P., Hiariey, J. \& Lopulalan, Y. 2019, Faktor Produksi Dan Pekembangan Produksi Usaha Budidaya Rumput Laut Kotoni Di Kabupaten Seram Bagian Barat, Jurnal Sosial Ekonomi Kelautan dan Perikanan, 13(2): 179-192. DOI: 10.15578/jsekp.v13i2.7270

Muharara, C.P. \& Satria, A. 2018. Analisis Tingkat Keberlanjutan Pengelolaan Kawasan Konservasi Perairan Daerah Berbasis Masyarakat, Jurnal Sains Komunikasi dan Pengembangan Masyarakat, 2(2):255-270. DOI: 10.29244/jskpm.2.2.255-270

Nirmala, K., Ratnasari, A. \& Budiman, S. 2014. Penentuan Kesesuaian Lokasi Budidaya Rumput Laut di Perairan Teluk Gerupuk - Nusa Tenggara Barat Menggunakan Penginderaan Jauh dan SIG. Jurnal Akuakultur Indonesia, 13(1):73-82.

Nugroho, A.S., Tanjung, S.D. \& Hendrarto, B., 2014, Distribusi Serta Kandungan Nitrat dan Fosfat di Perairan Danau Rawa Pening, Jurnal Ilmiah Biologi, 3(1):24-41. DOI: 10.26877/ bioma.v3i1,\%20April.648

Parenrengi, A., Rachmansyah, \& Suryati, E., 2012. Budi Daya Rumput Laut Penghasil Karaginan (Karaginofit). Balai Penelitian dan Pengembangan Budidaya Air Payau, Maros, 54 hlm. Pradnyana, I.W.G.W., \& Nugroho, S., 2019, Upaya Revitalisasi Pertanian Rumput Laut Dalam Praktik Pariwisata Di Desa Lembongan, Kabupaten Klungkung. Jurnal Destinasi Pariwisata, 7(2) 352-363. DOI: 10.24843/JDEPAR.2019.v07.i02.p21

Prahasta, E, 2002, Konsep-konsep Dasar Sistem Informasi Geografi, Informatika Bandung, Bandung. Priono, B., 2016. Budidaya Rumput Laut Dalam Upaya Peningkatan Industrialisasi Perikanan, Media Akuakultur, 8(1):1-8. DOI: 10.15578/ma.8.1.2013.1-8

Radiarta, I. N., Erlania \& Haryadi, H., 2018. Analisis Kesesuaian dan Daya Dukung Perairan untuk Pengembangan Budidaya Rumput Laut di Kabupaten Simeulue, Aceh, Jurnal Segara 14(1):11-22. DOI: 10.15578/segara.v14i1.6626

Susanto, A. B., 2005. Metode Lepas Dasar Dengan Model Cidaun Pada Budidaya Eucheuma spinosum (Linnaeus) Agardh. Indonesian Journal of Marine Sciences, 10(3):158164. DOI: 10.14710/ik.ijms.10.3.158-164

Valderrama, D., Cai, J., Hishamunda, N., \& Ridler, N., 2013. Social And Economic Dimensions Of Carrageenan Seaweed Farming, Rome, Italy.

Valentino, G., Damai, A.A., \& Yulianto, H., 2018. Analisis Kesesuaian Perairan Untuk Budidaya Ikan Kerapu Macan (Epinephelus fuscoguttatu) Di Perairan Pulau Tegal Kecamatan Teluk Pandan Kabupaten Pesawaran, e-Jurnal Rekayasa dan Teknologi Budidaya Perairan, 6(2): 705-712. DOI: 10.23960/jrtbp.v6i2.p705-712

Yuliyana, A., Rejeki, S. \& Widowati, L.L. 2015. Pengaruh Salinitas Yang Berbeda Terhadap Pertumbuhan Rumput Laut Latoh (Caulerpa lentillifera) Di Laboratorium Pengembangan Wilayah Pantai (LPWP) Jepara. Journal Aquaculture Management and Technology, $4(4): 61-66$. 